\title{
Rapid and sensitive reverse transcriptase- polymerase chain reaction based detection and differential diagnosis of fish pathogenic rhabdoviruses in organ samples and cultured cells
}

\author{
T. A. Miller ${ }^{1,2}$, J. Rapp${ }^{1}$, U. Wastlhuber ${ }^{1}$, R. W. Hoffmann ${ }^{3}$, P.-J. Enzmann ${ }^{2, *}$ \\ ${ }^{1}$ Staatliches Tierärztliches Untersuchungsamt Aulendorf, Löwenbreitestr. 18/20, D-88326 Aulendorf, Germany \\ ${ }^{2}$ Bundesforschungsanstalt für Viruskrankheiten der Tiere, Paul-Ehrlich-Str. 28, D-72076 Tübingen, Germany \\ ${ }^{3}$ Institut für Zoologie, Fischerei und Fischkrankheiten, Kaulbachstraße 37, D-80539 München, Germany
}

\begin{abstract}
A reverse transcriptase-polymerase chain reaction (RT-PCR) assay was developed and applied to the detection and differentiation of viral haemorrhagic septicaemia virus (VHSV) and infectious hematopoietic necrosis virus (IHNV) in organ samples and cultured cells, regardless of the serotype. This method was developed by selecting primer sets corresponding to highly conserved regions of the glycoprotein G-gene sequences of the 2 viruses. The very fast RNA extraction, reverse transcription and PCR permitted us to read the agarose gels within 7 to $9 \mathrm{~h}$ after samples, cultured cells and whole fish arrived, which is of great importance when there is reason to believe that VHSV or IHNV may be present. This is also the first report of a large-scale field trial comparing the RT-PCR assay in trout from 30 German fish farms (a total of 330 rainbow trout) with the usual virus isolation and identification method in order to evaluate the efficiency of the RT-PCR assay for general use in fish health management programs. RT-PCR followed by semi-nested PCR using RNA directly extracted from fish tissue turned out to be the most sensitive method. It recognized 9 fish farms as VHS-positive and 7 as IHN-positive. This is 3 VHS- and $4 \mathrm{IHN}$-farms more than detected by the traditional virus isolation method. By directly examining the tissue by means of a PCR test it was possible to deteci viral RNA in acutely and subacutely to chronically diseased fish as well as in asymptomatic VHS/IHNcarrier fish. Therefore, this effective and powerful assay for detecting VHSV and IHNV by means of PCR has great advantages compared with the presently used procedures
\end{abstract}

KEY WORDS: RT-PCR - VHSV/IHNV - Differential diagnosis in organ samples

\section{INTRODUCTION}

Aquatic rhabdoviruses such as viral haemorrhagic septicaemia virus (VHSV) and infectious hematopoietic necrosis virus (IHNV) are significant pathogens for salmonids. VHSV and IHNV often causes diseases with high mortality among salmonids, especially in rainbow trout Oncorhynchus mykiss.

Since its first isolation (Jensen 1965) VHSV has been widely detected in Europe. VHSV was first isolated in

•E-mail: enzmann@tue.bfav.de
1988 in chinook salmon Oncorhynchus tshawytscha and in coho salmon $O$. kisutch on the West coast of North America (Brunson et al. 1989, Hopper 1989). Virus isolations from Pacific cod Gadus macrocephalus and Alaskan Pacific herring Clupea harengus pallasi were reported in 1992 and 1993, respectively (Meyers et al. 1992, 1993). It was concluded that VHSV had been enzootic in the North Pacific region for some time (Batts et al. 1993). Even in the British Isles, thought to be VHSV-free, VHSV was isolated from a turbot Scophthalmus maximus farm in Scotland (Ross et al. 1994). Experimental infection showed that this turbot isolate was of low virulence for rainbow trout 
and salmon (Munro 1996). Furthermore VHSV was found on a island off the Irish coast (J. McArdle pers comm. 1997)

IHNV was originally isolated from a sockeye salmon Oncorhynchus nerka population on the west coast of North America, but soon spread to rainbow trout. In 1977 IHNV spread to Japan (Sano et al. 1977). In 1987 IHNV was detected in France and Italy (BaudinLaurencin 1987, Bovo et al. 1987). IHNV-isolation was also reported in Belgium (F. Lieffrig pers. comm. 1995). In Switzerland, the first virus isolation was reported in 1988 (Anonymous 1988). In the cantons Aargau and Tessin IHNV was discovered in 1993 (W. Meier pers. comm.). In 1995 there were many outbreaks in Italy (G. Bovo pers. comm.) and in France (P. de Kinkelin pers. comm.). In the summer of 1992 IHN also reached Germany (Enzmann et al. 1992). Since then a series of IHN outbreaks has been reported in various parts of Germany.

The above-mentioned data indicate that in Europe both viruses were spread by trading of fish. The fact that in Germany the demand for trout and trout eggs is only partially met by inland produce increases the danger of a further spread of VHSV and also IHNV through import of fish which have not been inspected This demonstrates the need for a fast and reliable diagnostic method.

It is important that the causative agents of these fish diseases are rapidly identified and differentiated because quick determination of the origin of an outbreak may help to prevent the further spread of the disease.

Arakawa et al. (1990) were the first group using the PCR techrique to detect IHNV. They used primers specific for the N-gene. Cloning and sequencing of cDNAs of IHNV and VHSV glycoprotein genes (Koener et al. 1987. Thiry et al. 1991) revealed considerable differences at the nucleotide as well as at the amino acid level. To distinguish IHNV and VHSV by RT-PCR, Bruchhof. et al. (1995) used primer pairs designed for the amplification of glycoprotein G-specific gene fragments of the 2 viruses. These PCR products were amplified from RNA extracts of RTG-2 cells infected with a total of 9 different strains of either VHSV or IHNV. This RT-PCR amplification of VHSV or IHNV G-genes was found to be a highly specific and sensitive method. Therefore, oligodeoxynucleotide primers corresponding to the G-genes were applied in this study to detect and to differentiate between IHNV and VHSV by means of RT-PCR applied directly to organ samples (heart, spleen, anterior kidney and brain) and to different infected cultured cells (Epithelioma Papulosum Cyprini, EPC; Rainbow Trout Gonad, RTG2).

\section{MATERIALS AND METHODS}

Fish samples. We tested 330 rainbow trout of various sizes (2 to $500 \mathrm{~g}$ ). The fish originated from 30 German fish farms which either had been proved to be VHSV/ IHNV-infected or were expected, on the grounds of clinical diagnosis, to be VHS/IHN-diseased. Five different fish health services from 4 German federal states helped by sending either fresh or frozen ( 20 or $-70^{\circ} \mathrm{C}$ ) whole fish. All farms which had sent fish were allocated numbers in ascending sequence. The gross pathological examination and the removal of organs were carried out in all cases in the Aulendorf fish health laboratory. Here all samples were also tested for VHSV and IHNV, using the following methods, regardless of clinical signs and autopsy findings (acutely VHS/IHN-diseased or VHS/IHN symptomfree).

Ceilis and viruses. Nine reference strains of VHSV and IHNV and the viruses isolated from the fish specimens were grown in monolayer cultures of EPC and RTG2 cells. These cell lines were obtained from the national reference laboratory, Riems, Germany.

The following VHSV strains were used as reference strains: F1, He, group II and III (Olesen et al. 1993), all of which were obtained from the EU reference laboratory, Aarhus, Denmark. Type 23.75 was obtained from P. de Kinkelin, Jouy-en-Josas, France. Strain Fi13 is the German reference strain F1. Its growth requirements were described earlier (Enzmann \& Bruchhof 1989). IHNV strains RB, WRAC and SRCV were obtained from the Marine Science Center, Newport, Oregon, USA.

Virus isolation and detection by immunofluorescent antibody test (IFAT). The organ samples (heart, spleen, anterior kidney, brain) were homogenised in an antibiotic-supplemented culture medium and EPC and RTG2 cells were infected with serial dilutions of the samples, following the prescribed method (Commission of the European Communities 1996). These pools of 10 fish were based on the same individuals used for the PCR assay.

The detection of VHSV and IHNV by IFAT in cell cultures was carried out with the Bio-Fluo VHS and IHN Kit (BioX, Belgium), following the protocol recommended by the supplier.

Synthetic oligonucleotide primers. The primers for VHSV and IHNV serotypes were designed by comparison of G-gene sequences from different VHSV- and IHNV-strains (P.-J. Enzmann unpubl.). All oligonucleotides were synthesised by Roth (Karlsruhe, Germany). The annealing sites of the primers are shown in Fig. 1 and their sequences are as follows 


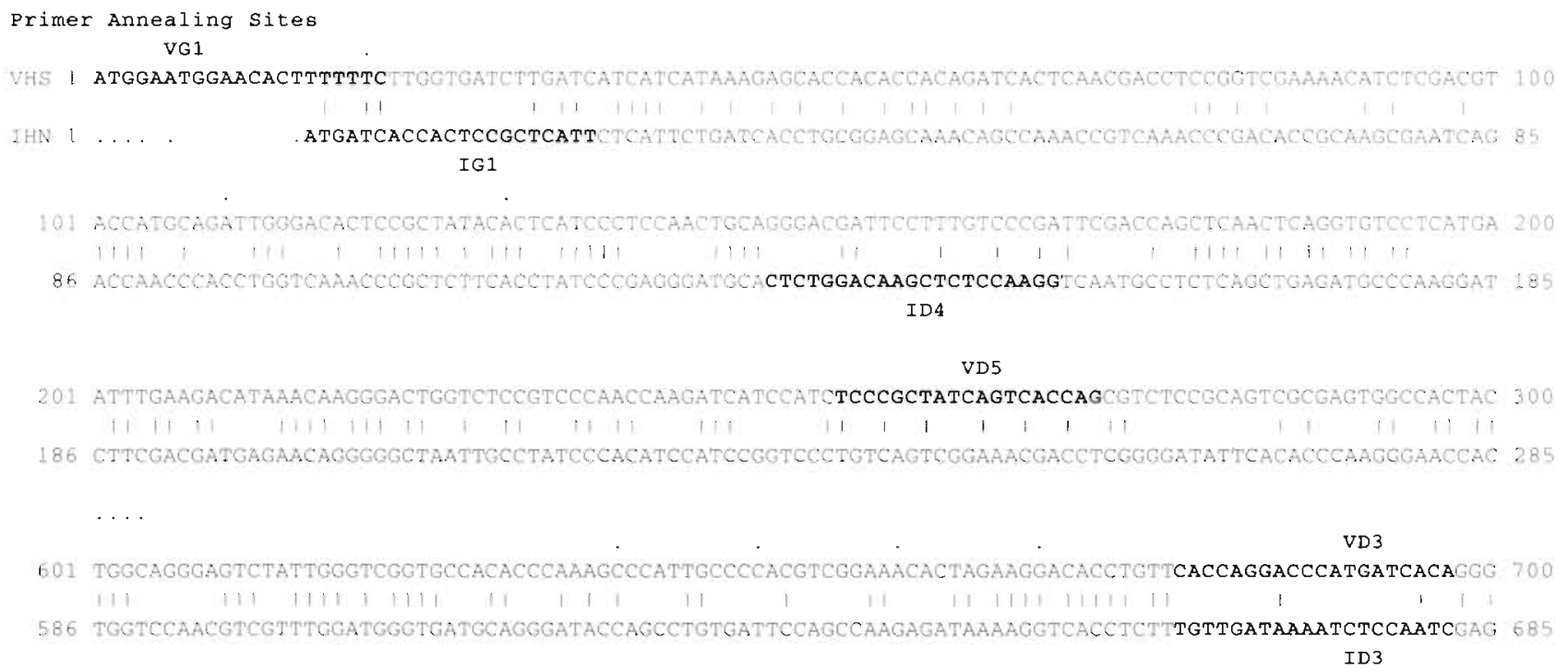

Fig. 1. Alignment of cDNA fragments of the glycoprotein gene of VHSV (strain Fi13) and IHNV (strain RB). Positions of the sense primers (VHS: VG1 and VD5; IHN: IG1 and ID4) and the antisense primers (VHS: VD3; IHN: ID3) shown in bold

VG1: (VHSV G-gene 1), sense primer, position ${ }^{\mathrm{a}} 1-21^{\mathrm{b}}$ : 5'-ATGGAATGGAACACTTTTTTC-3'

VD5: (VHSV diagnosis 5), sense primer, position ${ }^{a}$ 254-272: 5'-TCCCGCTATCAGTCACCAG-3'

VD3: (VHSV diagnosis 3), antisense primer, position ${ }^{a}$ 678-697: 5' -TGTGATCATGGGTCCTGGTG-3'

IG1: (IHNV G-gene 1), sense primer, position ${ }^{\alpha} 1-21^{c}$ : 5'-ATGATCACCACTCCGCTCATT-3'

ID4: (IHNV diagnosis 4), sense primer, position ${ }^{\text {a }}$ 134-154: 5'-CTCTGGACAAGCTCTCCAAGG-3'

ID3: (IHNV diagnosis 3), antisense primer, position ${ }^{\text {a }}$ 663-682: 5'-GATTGGAGATTTTATCAACA-3'

RNA extraction from organ samples and infected cells. Total RNA was extracted with RNeasy Total RNA Kit (Qiagen) according to the manufacturer's instructions. 330 rainbow trout were examined individually. However, the organs of each fish (heart, spleen, anterior kidney and brain) were pooled for the subsequent PCR test. The remaining organ samples were stored for further tests at $-70^{\circ} \mathrm{C}$. In routine diagnostic work 5 to $50 \mathrm{mg}$ of organ (heart, spleen, kidney and brain) or $10^{5}$ infected EPC or RTG2 cells were used for isolation of viral RNA, but for RT-PCR $10^{3}$ cells were sufficient.

All samples were lysed in guanidinium isothiocyanate (Chomczynski \& Sacchi 1987) and incubated for 5 min at room temperature. The following steps were described in the RNeasy Protocol.

\footnotetext{
Numbering of nucleotides according to the open reading frame (start codon ATG)

${ }^{b}$ According to Thiry et al. (1991)

'According to Koener et al. (1987)
}

The purified RNA was usually eluted in 30 to $100 \mu l$ RNase-free water. The quality and the quantity of the purified nucleic acids were determined by measuring the absorbance at $260 \mathrm{~nm}\left(\mathrm{~A}_{260}\right)$ and $280 \mathrm{~nm}\left(\mathrm{~A}_{280}\right)$ in a spectrophotometer (Zeiss, M4QIII + PMQII + H30DS). As negative controls, non-infected cells, RNase-free water and uninfected fish tissue were used. These control fish originated from 10 different fish farms which had been proved to be VHSV- or IHNV-free.

Reverse transcription and PCR amplification (RTPCR). For first strand cDNA synthesis (reverse transcription) $15 \mu$ total RNA extracted by the above procedure and $1 \mu$ sense primer (for genomic RNA: VG1 or IG1, 15 pmol each) were preheated at $70^{\circ} \mathrm{C}$ for 5 min. Then the reverse transcription buffer mixture was made up to a final volume of $25 \mu$ l according to the protocol recommended by the supplier and incubated at $42^{\circ} \mathrm{C}$ for $60 \mathrm{~min}$ (AMV Reverse Transcriptase, Promega). Following reverse transcription, $8 \mu \mathrm{l} c D N A$ was added to the PCR mixture containing $15 \mathrm{pmol}$ sense and antisense primer, $0.25 \mathrm{mM}$ of each dNTP, $2.5 \mathrm{mM} \mathrm{MgCl}_{2}, 10 \mathrm{mM}$ Tris- $\mathrm{HCl}$ at pH 9.0,50 mM KCl, $0.1 \%$ Triton X-100, $1.5 \mathrm{U}$ Taq DNA Polymerase (Promega), and water up to a final volume of $100 \mu$ l. The target region expected to be amplified from VG1 to VD3 is TV1 (697 base pairs, bp) and the target region from IG1 to ID3 is TI1 (682 bp).

Amplification and reverse transcription were performed in a thermal cycler with a heated lid, which eliminates the need for mineral oil overlays (PTC-100 thermal cycler, MJ Research Inc.). The PCR program started with an initial cycle at $95^{\circ} \mathrm{C}$ for $1 \mathrm{~min}$, followed by $30 \mathrm{~s}$ at $95^{\circ} \mathrm{C}, 40 \mathrm{~s}$ at $52^{\circ} \mathrm{C}$ and $40 \mathrm{~s}$ at $72^{\circ} \mathrm{C}$ (repeated 
for 40 cycles). A final extension step, $5 \mathrm{~min}$ at $72^{\circ} \mathrm{C}$, completed the reaction. The time required for PCR was $125 \mathrm{~min}$

PCR product analysis. After amplification, $8 \mu \mathrm{l}$ of PCR products were electrophoresed at $60 \mathrm{~V}$ for $10 \mathrm{~min}$ and at $80 \mathrm{~V}$ for $40 \mathrm{~min}$ in TAE buffer on $1.3 \%$ agarose gels, stained with ethidium bromide $\left(0.5 \mu \mathrm{g} \mathrm{ml}^{-2}\right)$. DNA molecular weight marker type $100 \mathrm{bp}$ DNA ladder (TaKaRa) was applied to identify the size of the PCR products. The result of the agarose gel electrophoresis was analysed using a MacroVue transilluminator (Pharmacia Biotech) and documented with Polaroid MP4+ instant foto system (Instant Pack Film, Polaroid Type 667)

Authenticity of PCR products amplified by using primers corresponding to the G-genes of VHSV and IHNV was demonstrated by direct sequencing of the PCR products (Sanger et al. 1977) and by restriction enzyme digestion, using Fok I (Bruchhof et al. 1995)

Semi-nested PCR amplification. Unless the first PCR produced VHS-positive or IHN-positive results, the semi-nested PCR amplification, using $2 \mu l$ RT-PCR products (TV1, TI1) as template, was performed immediately. The target region expected to be amplified from VD5 to VD3 is TV2 (444 bp) and the target region for ID4 to ID3 is TI2 (549 bp). The same reaction conditions were used as described above. The following amplification program was used: (1) initial $1 \mathrm{~min}$ at $95^{\circ} \mathrm{C}_{i}$ (2) $30 \mathrm{~s}$ at $93^{\circ} \mathrm{C}$ (3) $40 \mathrm{~s}$ at $52^{\circ} \mathrm{C} ;$ (4) $40 \mathrm{~s}$ at $72^{\circ} \mathrm{C}$; repeating steps (2) to (4) for 25 cycles. The total cycle time was $85 \mathrm{~min}$.

Multiplex PCR. This RT-PCR was developed for simultaneous detection and differential diagnosis of VHSV and IHNV in a single reaction tube. The cDNA synthesis and amplification conditions were changed as follows. For this reverse transcription 2 sense primers (VG1 and ID4; 15 pmol each) were added to total RNA before preheating at $70^{\circ} \mathrm{C}$ for $5 \mathrm{~min}$.

The PCR mixture consisted of 4 primers: VG1, VD3 ID4, ID3 (15 pmol each). The expected PCR products from VG1 to VD3 (TV1, $697 \mathrm{bp}$ ) and from ID4 to ID3 (T12, $549 \mathrm{bp})$, respectively, were analysed as above.

\section{RESULTS}

\section{Clinical signs and pathological changes}

Among 330 rainbow trout tested, there were acutely diseased fish as well as fish which were clinically asymptomatic for VHS or IHN. Acute signs of VHSV/ IHNV-infection were observed in trout originating from the following fish farms: 10, 15, 21, 23, 24, 26 and 28 . Some trout from fish farms 12, 22 and 29 had only a few signs of disease, such as pale gills and anaemia of the internal organs, i.e. fish with a subacute to chronic infection. The fish from the remaining farms showed no signs of a VHSV/IHNV-infection. The sample from fish farm No. 19 was an exception, because it arrived in an autolyzed condition due to transport problems and therefore a meaningful gross pathological examination was not possible.

\section{Reverse transcription and PCR amplification}

Total RNA extracted from the fish samples was subjected to RT-PCR and nested PCR amplification using oligonucleotide primers specific to the G-gene. These primers were designed according to the sequences from 17 VHSV strains and 5 IHNV strains (P.-J. Enzmann unpubl.) using the criterion of minimal sequence homology. Fig. 1 shows the alignment of VHSV strain Fi13 and IHNV strain RB and the position of the primers. Prolonging the reverse transcription period for more than $60 \mathrm{~min}$ at $42^{\circ} \mathrm{C}$ and increasing the AMV Reverse Transcriptase concentration had no effect on the efficiency of the reaction. Reverse transcription of the RNA was most successful with the sense primers (for genomic RNA) VG1 and IG1, respectively.

Fig. 2 (lanes 1 \& 2) shows the results of RT-PCR using the primer pair (VG1-VD3) for the VHS target region TV1 (697 bp) and the primer pair (IG1-ID3) for the IHN target region TI1 (682 bp). The results of semi-nested $\mathrm{PCR}$ in the presence of the internal primer sets (VD5VD3 for VHS and ID4-ID3 for (HN) are shown in Fig. 2 (lanes 5 \& 6). VD5-VD3 flank the target TV2 (444 bp)

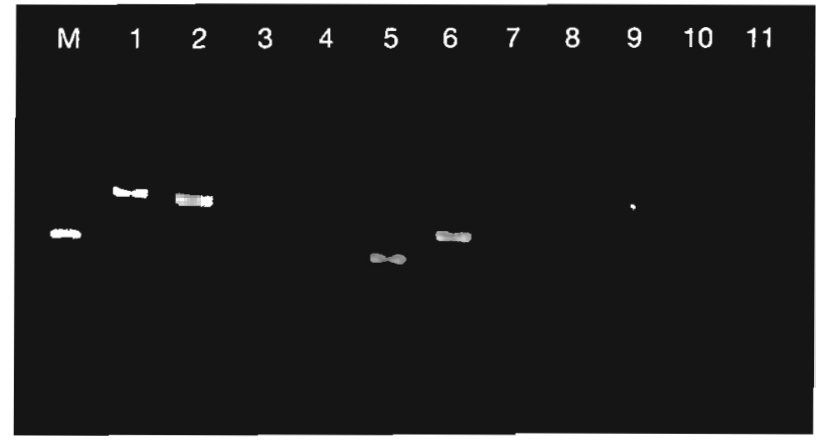

Fig. 2. Agarose gel showing the identification of VHSV/IHNV in rainbow trout tissue by $\mathrm{RT}$-, nested-and multiplex PCR. Marker (M): $100 \mathrm{bp}$ DNA ladder (triple the mass in $500 \mathrm{bp}$ band). Lanes 1-4: RT-PCR. (1) VHS primer set, VHS- and IHN-RNA template; (2) IHN primer set, VHS- and IHN-RNA

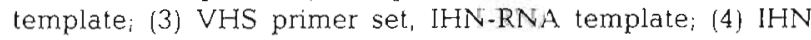
primer set, VHS-RNA template. Lanes 5-8: Nested PCR. (5) VHS primer set, VHS- and IHN-DNA template; (6) IHN primer set, VHS- and IHN-DNA template; (7) VHS primer set, IHN-DNA template; (8) IHN primer set, VHS-DNA template. Lanes 9-12: Multiplex PCR. (9) VHSV-positive; (10) IHNVpositive sample; (11) negative control 
and the target region from ID4 to ID3 is TI2 (549 bp). The expected multiplex PCR products from VG1 to VD3 and from ID4 to ID3 were TV1 (697 bp) and TI2 (549 bp), respectively, as shown in Fig. 2, lanes $9 \& 10$. As expected, PCR products of these sizes were amplified.

\section{Differential diagnosis of VHSV and IHNV by RT-PCR}

To differentiate between VHSV and IHNV, the selected primers from regions with substantial sequence divergence were used. Therefore, these oligonucleotides exclusively primed synthesis of the homologous templates. This was confirmed by reactions containing (1) a mixture of VHSV and IHNV RNA and only one primer set and (2) either the homologous or the heterologous RNA. In both cases only the homologous PCR product was amplified. The results are shown in Fig. 2, lanes 1 to 8.

\section{VHS and IHN diagnosis in 30 'at risk' fish farms}

The project involved the examination of rainbow trout from 30 German fish farms. Some of these farms were known to have a history of VHS or IHN (Tables $1 \& 2$ ). The status of the remaining farms with respect to VHS or IHN was unknown.

All samples received were examined using 3 different methods:

(A) Virus isolation in cell cultures, followed by IFAT.

(B) Virus isolation in cell cultures, followed by RT-PCR.

(C) Virus detection by RT-PCR directly from organ samples.

In the case of (B) and (C) the semi-nested PCR (method B2, C2 respectively) was also used. A multiplex PCR direct from tissue (method C3) was also performed. The results are presented in Table 1 (VHSpositive farms) and in Table 2 (IHN-positive farms).

The RT-PCR followed by the semi-nested PCR elicited directly from organ material (C2) was the most sensitive method, detecting 9 fish farms as VHS-positive and 7 as IHN-positive. Using the direct PCR-test of organ samples, viral RNA was detected in acute cases (VHS: $10,15,23,24$; IHN: 21, 26, 28) as well as in subacute to chronic cases (VHS: $12,22,29$ ) and in subclinically infected fish originating from VHS-positive farm 9 and from IHN-positive farms 2, 3, 25 and 27 (Tables $1 \& 2$ ).

Virus propagation in cell culture and identification by IFAT (A) gave comparable results to RT-PCR (B1) and semi-nested PCR (B2) using virus grown in cultured cells. In contrast, RT-PCR using RNA directly extracted from infected fish (C1) revealed a higher
Table 1. Positive test results for VHSV in 9 of 30 examined fish farms. A: Virus isolation in cell cultures, followed by IFAT. B1. Virus isolation in cell cultures, followed by RT-PCR. B2: Virus isolation in cell cultures, followed by RT- and nested PCR. C1 Virus detection by RT-PCR, directly from organ samples. C2: Virus detection by RT- and semi-nested PCR directly from organ samples. C3: Virus detection by multiplex PCR, directly from organ samples

\begin{tabular}{|c|c|c|c|c|c|c|c|c|}
\hline $\begin{array}{l}\text { Farm } \\
\text { no. }\end{array}$ & History & $\begin{array}{l}\text { Stage of } \\
\text { infection }\end{array}$ & A & B1 & $\mathrm{B} 2$ & $\mathrm{C} 1$ & $\mathrm{C} 2$ & C3 \\
\hline $9^{\text {a }}$ & VHS & Subclinical & + & + & + & + & + & - \\
\hline $10^{\mathrm{s}}$ & VHS & Acute & + & + & + & + & + & - \\
\hline $12^{b}$ & VHS & Subacute $^{c}$ & - & - & - & + & + & - \\
\hline 15 & - & Acute & + & + & + & + & + & - \\
\hline 19 & VHS & $--^{d}$ & - & - & - & + & + & - \\
\hline $22^{b}$ & VHS & Subacute & - & - & - & + & + & + \\
\hline 23 & - & Acute & + & + & + & + & + & + \\
\hline 24 & -- & Acute & + & + & + & - & + & - \\
\hline $29^{\text {त }}$ & VHS & Subacuter & + & + & + & + & + & - \\
\hline \multicolumn{3}{|c|}{$\begin{array}{l}\text { No. of fish farms detected } \\
\text { as VHSV-infected }\end{array}$} & 6 & 6 & 6 & 8 & 9 & 2 \\
\hline \multicolumn{9}{|c|}{$\begin{array}{l}\text { "These samples could only be identified in IFAT using a } \\
\text { mAb developed in our laboratory (mAb ID } 8 \text { ) } \\
\text { 'Before these samples were sent to our laboratory, they } \\
\text { were frozen (to only }-20^{\circ} \mathrm{C} \text { ) for at least } 4 \text { mo } \\
\text { 'Subacute to chronic cases } \\
\text { dThis sample arrived in autolyzed condition due to a delay } \\
\text { in transport }\end{array}$} \\
\hline
\end{tabular}

Table 2. Positive test results for IHNV in 7 of 30 examined fish farms. Abbreviations as in Table 1

\begin{tabular}{|c|c|c|c|c|c|c|c|c|}
\hline $\begin{array}{l}\text { Farm } \\
\text { no. }\end{array}$ & History & $\begin{array}{l}\text { Stage of } \\
\text { infection }\end{array}$ & A & B1 & $\mathrm{B} 2$ & $\mathrm{Cl}$ & $\mathrm{C} 2$ & $\mathrm{C} 3$ \\
\hline 2 & IHN & Subclinical & - & - & - & + & + & - \\
\hline 3 & IHN & Subclinical & - & - & - & + & + & - \\
\hline 21 & IHN & Acute & + & + & + & + & + & + \\
\hline 25 & IHN & Subclinical & - & - & - & - & + & - \\
\hline 26 & IHN & Acute & + & + & + & + & + & + \\
\hline 27 & IHN & Subclinical & - & - & - & - & + & - \\
\hline 28 & - & Acute & + & + & + & + & + & + \\
\hline \multicolumn{3}{|c|}{$\begin{array}{l}\text { Number of fish farms detected } \\
\text { as IHNV-infected }\end{array}$} & 3 & 3 & 3 & 5 & 7 & 3 \\
\hline
\end{tabular}

degree of sensitivity. The multiplex PCR (method C3) gave similar results to the IHN-virus isolation methods (A and B), but was less successful for VHSV detection.

The PCR techniques, amplifying nucleic acids after their isolation from infected fish, permit a diagnosis within 1 working day ( $\mathrm{C} 1$ to $\mathrm{C} 3$ ). The results are depicted in Fig. 2.

\section{Detection of VHSV and IHNV in organs by PCR}

First, the 330 rainbow trout were examined individually by PCR using pools made from heart, spleen, ante- 


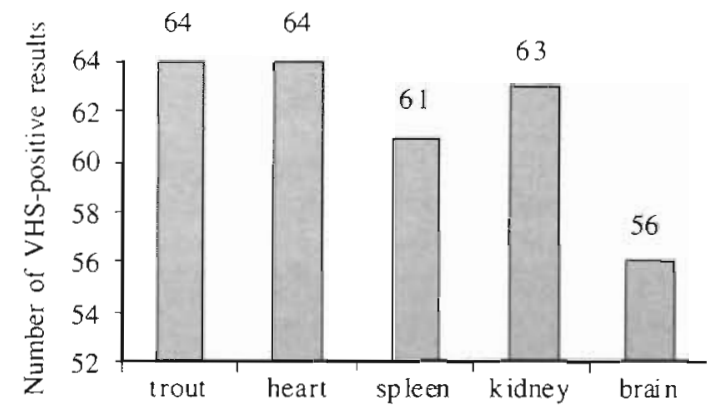

Fig. 3. Detection of VHSV in different tissues of Oncorhynchus mykiss. VHSV-distribution in different organs (heart, spleen, anterior kidney and brain) of 64 VHS-positive trout

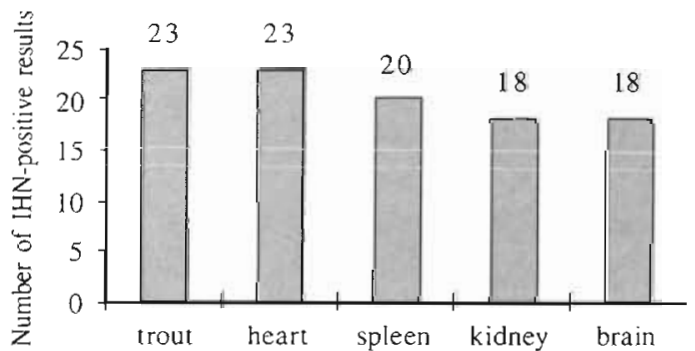

Fig. 4. Detection of IHNV in different tissues of Oncorhynchus mykiss. IHNV distribution in different organs (heart, spleen, anterior kidney and brain) of 23 IHN-positive trout

rior kidney and brain. VHSV was detected in 64 trout originating from fish farms $9,10,12,15,19,22,23,24$ and 29 (Table 1). From these farms a total of 92 fish were tested. It is noteworthy that fish from farm 9 were subclinically infected, i.e. there were no signs of disease. IHNV was detected in 23 fish originating from farms 2, 3, 21, 25, 26, 27 and 28 (Table 2). From these farms a total of 39 fish were tested. Again, there were subclinically infected fish found in farms 2, 3, 25 and 27.

In addition, the above-mentioned organs were examined individually for a pathogenic study. VHSV and IHNV were consistently detected in heart only (Figs. 3 $\& 4)$. Spleen, kidney and brain proved to be less efficient for virus detection. Figs. $5 \& 6$ demonstrate the typical results obtained by analyzing PCR products in agarose gels.

\section{DISCUSSION}

VHSV and IHNV are significant pathogens in aquaculture. These rhabdovirus infections often cause great losses among salmonids. Therefore, prevention of infection plays a major role. Regular control measures to be taken throughout Europe, laying down sampling plans and diagnostic methods for the detection and confirmation of certain fish diseases, have been re-

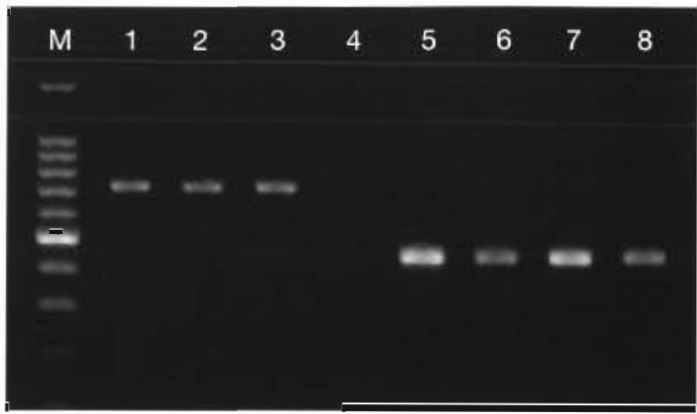

Fig. 5. Typical agarose gel showing the identification of VHSV in different tissues of Oncorhynchus mykiss. Marker (M): 100 bp DNA ladder (triple the mass in 500 bp band). Lanes 1-4: RT-PCR from (1) heart, (2) spleen, (3) anterior kidney, (4) brain. Lanes 5-8: RT- and semi-nested PCR from

(5) heart, (6) spleen, (7) anterior kidney, (8) brain

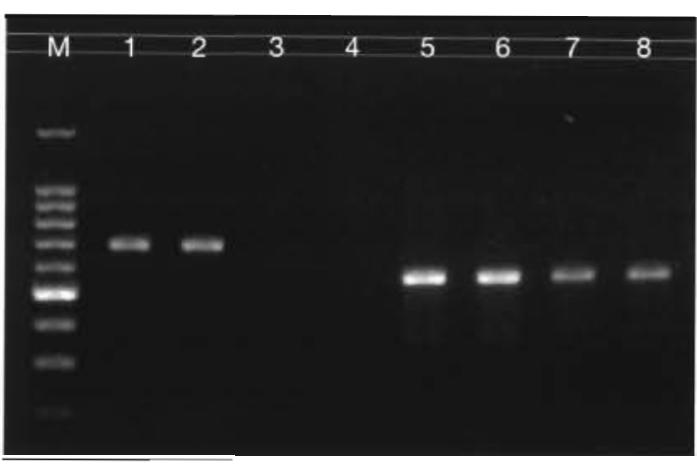

Fig. 6. Typical agarose gel showing the identification of IHNV in different tissues of Oncorhynchus mykiss. Marker (M): 100 bp DNA ladder (triple the mass in 500 bp band). Lanes $1-4$ : RT-PCR from (1) heart, (2) spleen, (3) kidney (posterior half), (4) brain. Lanes 5-8: RT- and semi-nested PCR from (5) heart, (6) spleen, (7) anterior kidney, (8) brain

commended by a Commission Decision (96/240/EC) (Commission of the European Communities 1996). Furthermore, limited fish health management programs have been carried out to combat VHS and IHN. At present, these aquatic rhabdoviruses are diagnosed mostly by IFAT after conventional virus isolation in cell cultures. This method, though it is time consuming, works very well in acute cases of VHS and IHN. But it is extremely difficult to detect virus in subclinically/ latently infected fish. VHSV and IHNV identification is also possible by means of the neutralization test (NT) and enzyme-linked immunosorbent assay (ELISA).

Different authors have reported on PCR methods which detected IHNV/VHSV in infected cell cultures (Arakawa et al. 1990, Bruchhof et al. 1995). However, until now there has been no reliable quick test for the direct detection of VHSV and IHNV in tissue specimens. We developed 4 primer sets, VG1-VD3 (VD5-VD3) and IG1-ID3 (ID4-ID3), corresponding to 
highly conserved nucleotide sequences in the G-genes of VHSV and IHNV, which are able to recognize all relevant types and variants of VHSV (F1, He, group II, group III, 23.75, Fi13) and IHNV (RB, WRAC, SRCV) including an attenuated strain of VHSV used as a vaccine by means of PCR (results not shown). The design of the primers proved to be in accordance with the published sequences from Stone et al. (1997) (valid for the primers VD3/ID3). Such a diagnostic test is valuable for fish health management programs worldwide and simplifies the control of these diseases.

The efficiency and suitability of this PCR method was tested in a field trial in which all samples were compared using both the traditional method of virus isolation and identification and PCR. The RT-PCR, followed by a semi-nested PCR applied directly to organ material, was the most sensitive method. From 30 fish farms tested, 9 farms were found to be VHS-positive and 7 farms to be IHN-positive. By means of a direct PCR test, using RNA isolated from organ samples, it was possible to detect acute cases as well as subacute to chronic cases and subclinically/latently infected fish.

In contrast, using the prescribed method (Commission of the European Communities 1996) only 6 farms were identified as VHS-positive and 3 as IHN-positive i.e. the PCR test detected 3 additional VHS-positive fish farms (Nos. 12, 19, 22) and 4 additional IHNpositive farms (Nos. 2, 3, 25, 27). These 7 fish farms were known to have a history of VHS or IHN. To be sure that these 7 PCR-positive cases were negative for VHSV and IHNV using traditional virus isolation methods, 3 blind passages were performed. In all cases no cytopathic effect was observed and no virus was detected using the IFAT or PCR technique with these cultured cells. It is noteworthy that fish from farms 12 and 22 had been frozen (to only $-20^{\circ} \mathrm{C}$ ) for at least $4 \mathrm{mo}$. In one case (farm No. 19) a decomposed sample was received due to a delay in transport. Nevertheless, it was possible to detect VHSV using the direct PCR technique. This higher sensitivity of the PCR technique may be explained by the fact that only viral gene fragments are needed and not an intact virus as is the case for the usual virus isolation method.

After propagation of a cytopathic agent in cell culture all identification tests (IFAT and PCR) gave similar results. Three of the isolated viruses (samples from farms 9, 10 and 29) did not react in the IFAT with the monoclonal antibody (mAb) supplied by BioX, Belgium. These samples could be identified in IFAT using a mAb (ID 8) developed in our laboratory as well as by RT-PCR with RNA isolated from cultured cells and by direct PCR tests using organ samples.

In order to detect VHSV and IHNV together in one single reaction tube, a multiplex PCR was performed; however, this method appears to be less sensitive for detection and differentiation of infectious agents (especially viruses) in patient samples (Bej et al. 1990). In the case of the IHNV multiplex PCR gave results similar to those of the virus isolation method (IHN-farm Nos. 21, 26, 28). But in the case of VHSV the results were insufficient, because only $2 \mathrm{VHSV}$-infected farms were detected (farm Nos. 22 and 23).

VHSV was found in 64 trout and IHNV was found in 23 trout from a total of 330 trout originating from a total of 30 farms. To demonstrate the distribution of VHSV and IHNV in different organs by means of the PCR technique, we tested heart, spleen, anterior kidney and brain from each fish individually. The heart proved to be the organ in which VHSV and IHNV were detected with the highest degree of effectivity. Further work is underway to test if pools with up to 10 fish affect the excellent sensitivity of the PCR method. Apart from the higher sensitivity of the PCR method, its rapidity is also important. Total RNA was successfully and rapidly (less than $1 \mathrm{~h}$ ) extracted with RNeasy Total RNA Kit (Qiagen) from cultured cells and tissue. The PCR technique, which amplifies nucleic acids after their isolation from tissue, permitted a diagnosis within 1 working day, in contrast to virus isolation and differentiation by cell cultures, where 14 to $20 \mathrm{~d}$ are required for a negative diagnosis. Furthermore, the testing time required increased by a further $7 \mathrm{~d}$, if the material was toxic for cells.

Fast and reliable tests are particularly important in fish virology. The PCR method described proved to be more sensitive and faster than currently used procedures. Therefore, this rapid VHSV/IHNV diagnostic test will be a valuable tool for fish health management programs.

Acknowledgements. This work was supported by the Akademie für Tiergesundheit e. $V_{1}$, Bonn-Bad Godesberg (7'96-12'97) and by the Ministerium für Ländlichen Raum, Baden Württemberg (from 1'98). We are greatly indebted to $M$. Huwer, $S$. Lechleiter, P. Martin, D. Mock, S. Müller and J.-W. Schäfer from the German fish health services for sending fish samples. The technical assistance of E. Dutt, I. Fabian, C. Mang and $\mathrm{C}$. Rahm is greatfully acknowledged. We are also grateful to K-H. Adam, J. E. Lohr, O. Marquardt and H. Stöppler for support and critical review.

\section{LITERATURE CITED}

Anonymous (1988) Bundesamt für Veterinärwesen. Infektiöse hämatopoietische Viruskrankheit (IHN), eine neue Seuche bedroht die Schweizer Forellenproduktion. In: Jahresbericht 1988 des Eidgenössischen Vakzineinstituts und der Untersuchungsstelle für Fischkrankheiten. Bundesamt für Veterinärwesen, Bern, p 197

Arakawa $\mathrm{CK}$, Deening RE, Higman KH, Oshima KH, O'Hara PJ, Winton JR (1990) Polymerase chain reaktion (PCR) 
amplification of a nucleoprotein gene sequence of infectrous hematopoietic necrosis virus. Dis Aquat Org 8: $165-170$

Batts WN, Ardkawa CK, Bernard J, Wınton JR (1993) Isolates of viral hemorrhagic septicemia virus from North America and Europe can be detected and distinguished by DNA probes. Dis Aquat Org 17:67-71

Baudin-Laurencin F (1987) IHN in France. Bull Eur Assoc Fish Pathol 7:104

Bej AK, Mahbubani MH, Miller R, Di Cesare JL. Haff L, Atlas RM (1990) Multiplex PCR amplification and immobilized capture probes for detection of bacterial pathogens and indicators in water. Mol Cell Probes 4:353-365

Bovo G, Giorgetti G, Jørgensen PEV, Olesen NJ (1987) Infectious haematopoietic necrosis: first detection in Italy. Bul Eur Assoc Fish Pathol 7:124

Bruchhof B, Marquart O, Enzmann PJ (1995) Differential diagnosis of fish pathogenic rhabdoviruses by reverse transcriptase-dependent polymerase chain reaction. J Virol Methods 55:111-119

Brunson R, True $\mathrm{K}$, Yancey J (1989) VHS virus isolated at Makah national fish hatchery. Fish Health Sect Newsl Am Fish Soc 17:3-4

Chomczynski P, Sacchi N (1987) Single-step method of RNA isolation by acid guanidinium thiocyanate-phenol-chloroform extraction. Anal Biochem 162:156-159

Commission of the European Communities (1996) Commis sion Decision (96/240/EC) of 5 February 1996 amending Decision 92/532/EEC laying down the sampling plans and diagnostic methods for detection and confirmation of certain fish diseases. Official Journal of the European Communities No. L 79/19-28

Enzmann PJ, Bruchhof B (1989) Comparative studies on viral haemorrhagic septicaemia viruses and infectious hematopoietic necrosis virus. An attempt to demonstrate an immunological relationship. In: Lillelund $\mathrm{K}$, Rosenthal H (eds) Fish health protection stategies. Bundesministerium für Forschung und Technologie, Bonn, p 107-120

Enzmann PJ, Dangschat $H$, Feneis B, Schmitt D, Wizigmann G. Schlotfeldt HJ (1992) Demonstration of lHN virus in Germany. Bull Eur Assoc Fish Pathol 12:185

Jensen $\mathrm{MH}$ (1965) Research on the virus of Egtved disease. Ann NY Acad Sci 126:422-426

Hopper K (1989) The isolation of VHSV from chinook salmon at Glenwood Springs, Orcas Islands, Washington. Am Fish Soc Fish Health Sect Newsl 17:1-2

Editorial responsibility: Larry Vaughan,

Dublin, Ireland
Koener JF, Passavant CW, Kurath G, Leong J (1987) Nucleotide sequence of a CDNA clone carrying the glycoprotein gene of infectious haematopoietic necrosis virus, a fish rhabdovirus. J Virol 61:1342-1349

Meyers TR, Short S, Lipson K, Batts WN, Winton MR, Brown E (1993) Isolation of North American viral haemorrhagic septicaemia virus (VHSV) from Alaskan Pacific herring, Clupea harengus pallasi. Fish Health Sect Newsl Am Fish Soc 21:1-2

Meyers TR, Sullivan J, Emmenegger E, Follett J, Short S, Batts WN, Winton JR (1992) Identification of viral haemorrhagic septicaemia virus isolated from Pacific cod Gadus macrocephalus in Prince William Sound, Alaska, USA. Dis Aquat Org 12:167-175

Munro ALS (1996) Report on the tirst recorded outbreak of viral haemorrhagic septicaemia (VHS) in GB and subsequent actions to contain, eradicate and investigate the origins of the infection. Scott Aquacult Res Rep 3:1-12

Olesen NJ, Lorenzen N, Jorgensen PEV (1993) Serological differences among isolates of viral haemorrhagic septicaemia virus detected by neutralizing monoclonal and polyclonal antibodies. Dis Aquat Org 16:163-170

Ross K, McCarthy U, Huntly PJ, Wood BP, Stuart D, Rough EI, Smail DA, Bruno DW (1994) An outbreak of viral haemorrhagic septicaemia (VHS) in turbot (Scophthalmus maximus) in Scotland. Bull Eur Assoc Fish Pathol 14: $213-214$

Sanger F, Nicklen S, Coulson AR (1977) DNA sequencing with chain-termination inhibitors. Proc Natl Acad Sci USA $74: 5463-5467$

Sano T, Nishimura T, Okamoto N, Yamazaki T, Hanada $H$, Watanabe Y (1977) Studies on viral diseases of Japanese fishes. VI. Infectious hematopoietic necrosis (IHN) of salmonids in the mainland of Japan. J Tokyo Univ Fish $63: 81$

Stone DM, Way K, Dixon PF (1997) Nucleotide sequence of the glycoprotein gene of viral haemorrhagic septicaemia (VHS) viruses from different geographical areas: a link between VHS in farmed fish species and viruses isolated from North Sea cod (Gadus morhua L.). J Gen Virol 78 : $1319-1326$

Thiry M, Lecocq-Xhonneux F, Dheur I, Renard A, de Kinkelin $P$ (1991) Sequence of a cDNA carrying the glycoprotein gene and part of the matrix protein M2 gene of viral haemorrhagic septicaemia virus a fish rhabdovirus. Biochim Biophys Acta 1090:345-347

Submitted: March 3, 1998; Accepted: June 12, 1998 Proofs received from author(s): September 2, 1998 